\title{
PEMBERDAYAAN MASYARAKAT MELALUI PENGEMBANGAN AGRIBISNIS JAMUR TIRAM PADA LAHAN PEKARANGAN DI DESA KARANG BARU LOMBOK TIMUR
}

\section{COMMUNITY EMPOWERMENT THROUGH DEVELOPMENT OF OYSTER MUSHROOM AGRIBUSINESS ON YARD IN KARANG BARU VILLAGE, LOMBOK TIMUR REGENCY}

\author{
Wuryantoro $\left.{ }^{1 *}\right)$, Candra $\mathrm{Ayu}^{1}$ \\ ${ }^{1}$ Program Studi Agribisnis, Fakultas Pertanian, Universitas Mataram \\ ${ }^{*}$ Korespondensi: wuryantorow@yahoo.com
}

Diterima 14 Oktober 2020 / Disetujui 23 November 2020

\begin{abstract}
ABSTRAK
Semakin terbatasnya ketersedian lahan, akibat alih fungsi lahan dan jumlah penduduk yang semakin bertambah, mendorong masyarakat untuk memanfaatkan lahan pekarangan sebagai alternatif dalam mengembangkan produk-produk pertanian. Desa Karang Baru merupakan salah satu desa yang terletak di Kecamatan Wanasaba Kabupaten Lombok Timur, memiliki luas lahan pemukiman dan pekarangan yang cukup luas yaitu $362 \mathrm{Ha}$. Namun, masyarakat masih belum bisa memanfaatkan lahan kosong pekarangan tersebut untuk kegiatan produktif. Tujuan kegiatan pengabdian pada masyarakat ini adalah untuk meningkatkan pengetahuan dan keterampilan, kesadaran serta memotivasi masyarakat khususnya ibu-ibu rumah tangga dalam pengembangan agribisnis jamur tiram di lahan pekarangannya serta meningkatkan pengetahuan peluang pasar dan potensi tambahan pendapatan yang dapat diperoleh dari pengembangan agribisnis jamur tiram tersebut. Dari hasil kegiatan yang telah dilakukan dapat ditarik kesimpulan bahwa: para peserta penyuluhan merespon positif dan berpartisipasi secara aktif terhadap seluruh kegiatan yang diprogramkan. Transfer iptek dapat berjalan dengan baik dimana para peserta kegiatan pengabdian telah mampu melakukan penanaman jamur tiram di halaman pekarangan mereka, serta mampu memahami teknik pengolahan jamur tiram serta potensi pasarnya. Peserta penyuluhan menyadari bahwa pemanfaatan lahan pekarangan dengan menanam jamur tiram dapat dijadikan sebagai sumber pangan dan pendapatan tambahan keluarga.
\end{abstract}

Kata Kunci: Lahan Pekarangan, Jamur tiram, Agribisnis, Pendapatan Keluarga

\section{ABSTRACT}

The increasingly limited availability of land, due to land conversion and increasing population, has encouraged communities to use the yard as an alternative in developing agricultural products. Karang Baru Village is one of the villages located in Wanasaba Subdistrict, East Lombok Regency, which has a large area of residential land and land which is $362 \mathrm{Ha}$. However, the community is still unable to utilize vacant land for productive activities. The aim of community service activities is to increase knowledge and skills, awareness and motivate the community, especially housewives in the development of oyster mushroom agribusiness in their yards and to increase knowledge of market opportunities 
and potential additional income that can be obtained from the development of oyster mushroom agribusiness. From the results of the activities that have been carried out it can be concluded that participants of the extension program responded positively and actively participated in all programmed activities. Science and technology transfer can run well, where the participants have been able to plant oyster mushrooms in their yard, and are able to understand oyster mushroom processing techniques and the potential market for these products. The extension participants realized that the use of the yard by planting oyster mushrooms could be used as a source of food and additional income for the family.

Key Words: Yard, Mushroom Oyster, Agribusiness, Family Income

\section{PENDAHULUAN}

\section{A. Latar Belakang}

Desa Karang Baru merupakan salah satu desa yang terletak di Kecamatan Wanasaba Kabupaten Lombok Timur, merupakan desa potensial yang terisolasi secara geografis dengan luas $891 \mathrm{Ha}$ dan terdiri dari 4 dusun. Desa karang baru memiliki luas pemukiman dan pekarangan seluas $365 \mathrm{Ha}$, persawahan $458 \mathrm{Ha}$, perkebunan $146 \mathrm{Ha}$, Kuburan 3,3 $\mathrm{Ha}$, perkantoran $0,15 \mathrm{Ha}$. Jumlah penduduk Desa Karang adalah 4137 jiwa dengan jumlah Kepala Keluarga sebanyak 1514 KK. Sekitar $90 \%$ penduduknya bermata pencaharian sebagai petani dan buruh tani, dengan rata kepemilikan lahan sawah kurang dari 0,3 ha (Wanasaba Dalam Angka, 2018).

Kondisi di atas menyiratkan bahwa di Desa Karang Baru bahwa ketersediaan lahan sawah yang bisa dikelola oleh petani semakin sempit, sementara ketersedian lahan pemukiman dan pekarangan masih cukup luas. Namun disisi lain masyarakat masih belum bisa memanfaatkan lahan kosong pekarangan rumah untuk kegiatan produktif. Letak geografis yang baik membuat keadaan alam di Desa Karang Baru sangat subur, hal tersebut membuat hampir semua komoditi pertanian dapat tumbuh dengan baik. Namun permasalahan yang dihadapi oleh masyarakat Desa Karang Baru adalahnya rendahnya pengetahuan dalam memanfaatkan lahan pekarangan untuk kegiatan produktif. Menurut Mardaharini dalam Ashari dan Saptana (2012), perhatian masyarakat terhadap pemanfaatan lahan pekarangan masih terbatas. Akibatnya pengembangan berbagai inovasi yang terkait dengan lahan pekarangan belum mencapai sasaran yang diharapkan. Padahal pemanfaatan lahan pekarangan untuk pengembangan berbagai produk pertanian seperti tanaman hortikultura berpotensi untuk dapat memenuhi kebutuhan seharihari keluarga.

Berdasarkan uraian potensi yang dimiliki masyarakat petani dan permasalahan yang dihadapinya di Desa Karang Baru maka diperlukan aktivitas produktif yang strategis dalam jangka pendek dapat meningkatkan produktivitas kerja dan pendapatan keluarga petani. Salah satu alternatif strategis ini adalah yang diusulkan untuk aktivitas Kegiatan Pengabdian Pengabdian pada Masyarakat ini, yakni pemberdayaan masyarakat melalui pengembangan usahatani agribisnis jamur tiram di halaman rumah atau di lahan pekarangan milik petani.

\section{B. Tujuan Kegiatan}

Tujuan dari program pengabdian masyarakat ini adalah : 
1. Meningkatkan pengetahuan dan keterampilan, kesadaran serta memotivasi masyarakat khususnya kelompok ibu-ibu rumah tangga dalam pemanfaatan lahan kosong/pekarangan sebagai sumber pangan/ ketahanan pangan dan pendapatan keluarga.

2. Menerapkan beberapa teknik penanaman dan pemeliharaan jamur tiram secara sederhana yang dapat diimplementasikan secara mudah oleh masyarakat.

3. Meningkatkan pengetahuan peluang pasar dan tambahan pendapatan yang dapat diperoleh dari pengembangan produk olahan jamur tiram

\section{METODE KEGIATAN}

Kegiatan pengabdian ini dilaksanakan di Desa Karang Baru Kecamatan Wanasaba Kabupaten Lombok Timur. Seperti yang diuraikan sebelumnya bahwa Desa Karang Baru merupakan desa yang subur serta memiliki potensi lahan pekarangan seluas $186 \mathrm{Ha}$, yang terisolasi dan secara geografis berada di kawasan kaki Gunung Rinjani. Dengan kondisi tersebut, permasalahan yang dihadapi oleh masyarakat Desa Karang Baru adalah:

1. Semakin sempitnya lahan pertanian yang dimiliki petani yang berdampak pada semakin rendahnya pendapatan yang diterima oleh keluarga petani

2. Rendahnya diversifikasi produk pertanian yang dihasilkan oleh petani. Petani Desa Karang Baru hanya terfokus pada usahatani padi dan jagung yang diusahakan di lahan sawah

3. Desa Karang Baru merupakan desa yang cukup terisolasi, sehingga akses terhadap pengetahuan keterampilan terkait pengembangan tanaman lainnya sangat terbatas

4. Minimnya pengetahuan yang dimiliki oleh masyarakat Desa Karang Baru terhadap pemanfaatan lahan pekarangan

5. Rendahnya jiwa kewirausahaan masyarakat, sehingga motivasi terhadap pemanfaatan potensi yang ada dalam upaya meningkatkan kesejahteraannya juga rendah.

Berdasarkan permasalahan yang dihadapi masyarakat Desa Karang Baru di atas maka metode yang digunakan dalam kegiatan pengabdian pada masyarakat ini adalah melakukan pemberdayaan masyarakat dengan rangkaian kegiatan sebagai berikut:

1. Melakukan penyuluhan terkait dengan potensi yang dimiliki masyarakat Desa Karang Baru, baik potensi kerja maupun sumber daya alam, guna menambah wawasan masyarakat terhadap potensi yang dimilikinya dan peluang untuk pemanfaatan potensi tersebut sebagai sarana untuk meningkatkan produksi

2. Melakukan penyuluhan tentang pengembangan agribisnis jamur tiram di halaman pekarangan milik masyarakat

3. Penumbuhan potensi dan motivasi berwirausaha masyarakat, khususnya kelompok perempuan akan meningkatkan pendapatan ekonomi dan kesejahteraan keluarga petani.

4. Untuk menguatkan dan mempercepat alih pengetahuan dan keterampilan serta teknologi budidaya dilakukan kegiatan praktek demo teknik bertanam dan memelihara jamur tiram dan potensi pengembangan produk olahannya. 
Dengan rangkaian kegiatan tersebut, diharapkan menjadi solusi masyarakat agar lebih berdaya dalam memanfaatkan potensi yang dimilikinya. Prinsip yang paling mendasar usaha pemberdayaan berhasil adalah prinsip bahwa untuk melakukan pemberdayaan masyarakat adalah dari, oleh, dan untuk masyarakat. Ini berarti, dibangun pada pengakuan serta kepercayaan akan nilai dan relevansi pengetahuan tradisional masyarakat serta kemampuan masyarakat untuk memecahkan masalah-masalahnya sendiri.

\section{HASIL DAN PEMBAHASAN}

Kegiatan pengabdian pada masyarakat ini dilaksanakan secara bertahap selama satu bulan, tepatnya dimulai pada di minggu pertama di bulan September 2019. Untuk mencapai tujuan yang sudah ditetapkan, pelaksanaan kegiatan pengabdian ini dilaksanakan dengan tahapan sebagai berikut:

\section{A. Tahap Sosialisasi dan Penyuluhan}

Sosialisasi ini dilakukan dengan cara menyebarkan informasi kepada masyarakat Desa Karang Baru, bahwa akan dilaksanakan kegiatan penyuluhan dan pelatihan terkait pengembangan agribisnis jamur tiram di lahan pekarangan serta produk olahannya. Sosialisasi dilakukan melalui Kepala Desa Karang Baru sekaligus menyerahkan Surat Tugas, dan selanjutnya tim penyuluhan dikenalkan dengan masyarakat calon peserta kegiatan penyuluhan. Tahap sosialisasi juga dimaksudkan untuk melakukan identifikasi potensi sumberdaya pertanian lahan, potensi kerja keluarga serta identifikasi masalah yang dihadapi masyarakat di lokasi, serta mensosialisasikan program pengabdian. Selain itu kegiatan tersebut juga digunakan untuk menjaring kelompok keluarga petani (suami dan istri) yang akan dijadikan sebagai peserta.

Kegiatan sosialisasi dan penyuluhan merupakan tahapan penting agar mau masyarakat memahami maksud tujuan dari diadakan kegiatan pengabdian oleh Tim Penyuluh Fakultas Pertanian Unram, serta untuk mengajak masyarakat mau berpartisipasi dalam kegiatan ini. Tanpa keterlibatan masyarakat maka dapat dikatakan bahwa pelaksanaan kegiatan pengabdian ini tidak berhasil. Oleh karena itu metode penyuluhan metode digunakan, adalah dengan tutorial dengan menggunakan LCD yang disertai dengan gambar-gambar menarik agar peserta tidak bosan, lebih akrab dengan tim penyuluh, serta tertarik untuk melakukan diskusi dan tanya jawab. Materi penyuluhan yang disampaikan kepada peserta terkait manfaat lahan pekarangan sebagai sumber pangan dan sumber tambahan pendapatan keluarga, budidaya jamur tiram secara sederhana, serta pengenalan produk olahan jamur tiram.

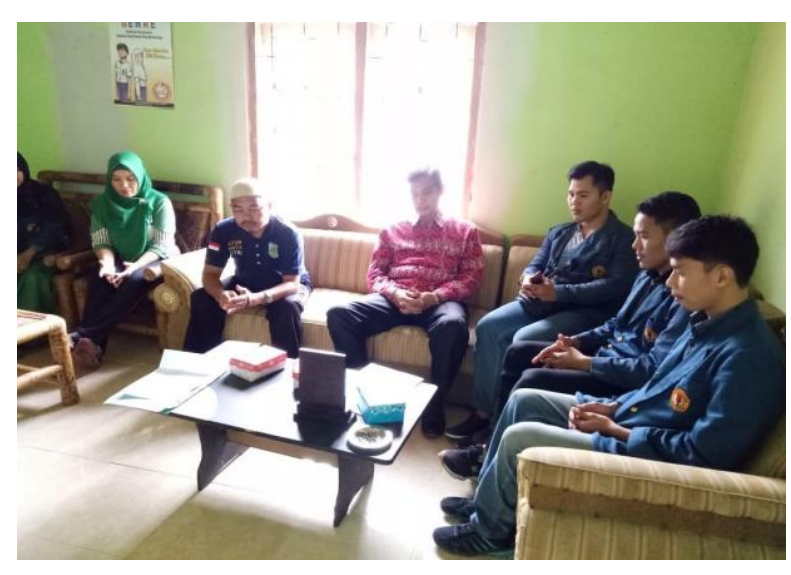




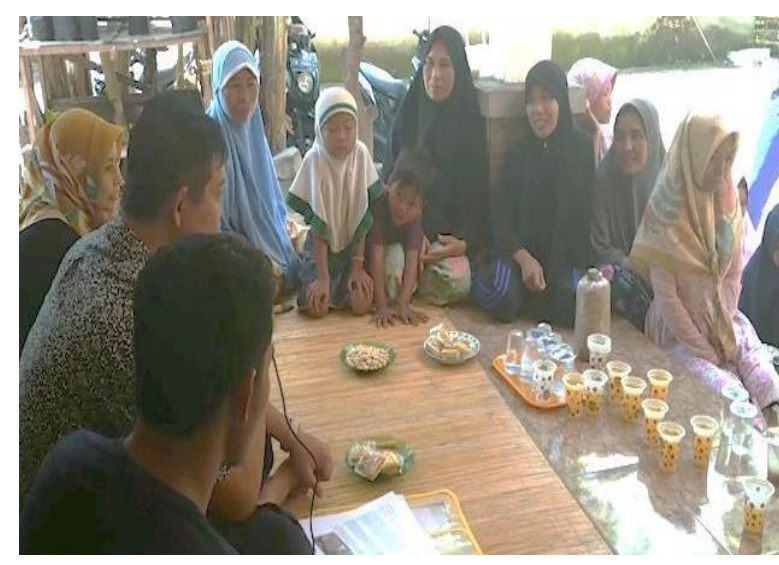

Gambar 1. : Kegiatan Penyerahan Surat Tugas dan Sosialisasi

Tahap Kegiatan Pengembangan Agribisnis Jamur Tiram

Setelah kegiatan sosialisasi dan perekrutan peserta pengabdian (penyuluhan), tahap berikutnya adalah

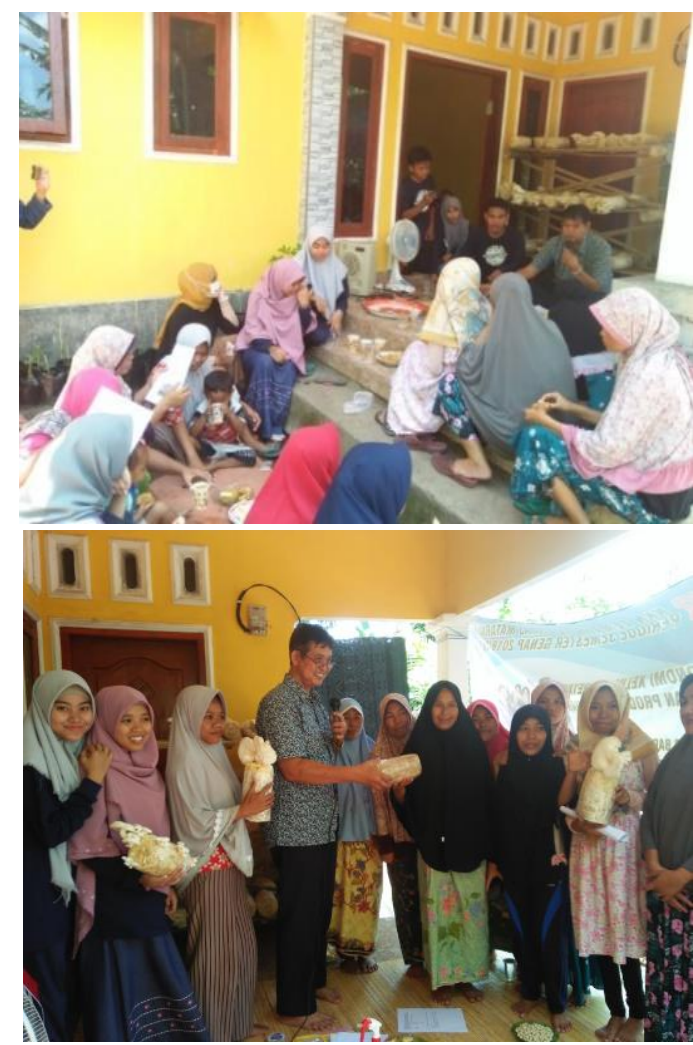

Gambar 2. Kegiatan Demo Perawatan Baglog Jamur Tiram

Kegiatan praktek perawatan dan pemeliharaan jamur tiram ini diawali dengan kegiatan praktek budidaya jamur tiram. Dalam kegiatan budidaya jamur tiram ini, kegiatan difokuskan pada perawatan dan pemeliharaan baglog yang sudah diinkubasi dengan bibit jamur tiram. Dalam kegiatan ini tim pengabdian tidak melakukan kegiatan pembudidayaan mulai dari pembibitan, namun kegiatan praktek budidaya dimulai dari perawatan pemeliharaan baglog jamur tiram, yakni dengan membeli bibit jamur tiram (baglog) yang sudah mulai banyak diperdagangkan. Pembudidayaan jamur tiram yang dimulai dari pembibitan sangat sulit dilakukan dan memerlukan sarana dan prasarana yang sangat mahal serta pengetahuan yang memadai di bidang pembibitan jamur tiram. Sehingga bagi pemula, pembelian bibit jamur tiram sangat dianjurkan karena lebih efisien. penyerahan baglog oleh tim pengabdian kepada peserta pengabdian. Sebelum penyerahan baglog peserta kegiatan pengabdian diminta untuk membuat rak-rak dari bambu yang digunakan untuk meletakkan baglog.

Tim pengabdian Unram selanjutnya mengajarkan cara merawat baglog jamur tiram yang benar. Ada tiga syarat agar jamur yang tumbuh dari baglog menghasilkan panen yang baik yaitu dengan memperhatikan kelembaban, udara dan suhu.

1. Kelembapan. Kelembaban ruangan sebaiknya di atas $70 \%$. Tingkat kelembaban bisa diukur dengan alat higrometer. Kelembaban ini diperlukan agar jamur bisa tumbuh dengan baik. Agar ruang ruangan kumbung tetap lembab, semprot baglog dengan air, usahakan menyemprotnya dengan semprotan kabut agar baglog tidak 
menerima terlalu banyak air pada saat yang sama, namun pastikan semprotannya jangan terlalu banyak. Karena jika kelembaban terlalu tinggi seperti saat musim hujan, jamur yang dihasilkan justru basah dan akan cepat rusak. Cara mengetahui jamur yang basah adalah dengan cara menekan jamur, jika keluar banyak air maka jamur tersebut terlalu basah. Jamur basah sendiri dihargai murah karena mudah membusuk. Pada musim hujan, perhatikan selalu kondisi kelembaban

2. Udara. Udara penting bagi pertumbuhan buah jamur. Jika udara kurang, jamur akan tumbuh memanjang untuk mencari udara. Pastikan plastik baglog terbuka cukup lebar agar miselium bisa mendapatkan oksigen yang cukup.Sirkulasi udara dalam kumbung juga perlu diperhatikan. Jangan sampai terjadi pertukaran udara yang berlebihan karena bisa menurunkan tingkat kelembaban di dalam kumbung yang membuat jamur kering dan tidak tumbuh.

3. Suhu. Suhu ruangan ideal ada di rentang 22-26 derajat celcius. Jika suhu terlalu panas, buah jamur yang masih kecil bisa kering dan tidak tumbuh lagi. Ciri jamur yang kering adalah warna kuning dan permukaan jamur mengeriput. Untuk menghindari kekeringan, semprot dengan air. Tetap perhatikan tingkat kelembaban dan kondisi jamurnya.

Selain kegiatan praktek cara merawat baglog, tim pengabdian juga memperkenal potensi pengambangan jamur tiram menjadi produk olahan yang memberikan nilai tambah yang tinggi dan bermanfaat. Setidaknya ada tiga produk olahan jamur tiram yang bermanfaat dan dapat memberikan nilai ekonomi yang tinggi, yaitu Jamur Crispy, Dendeng Jamur Tiram, dan Sate Jamur Tiram.
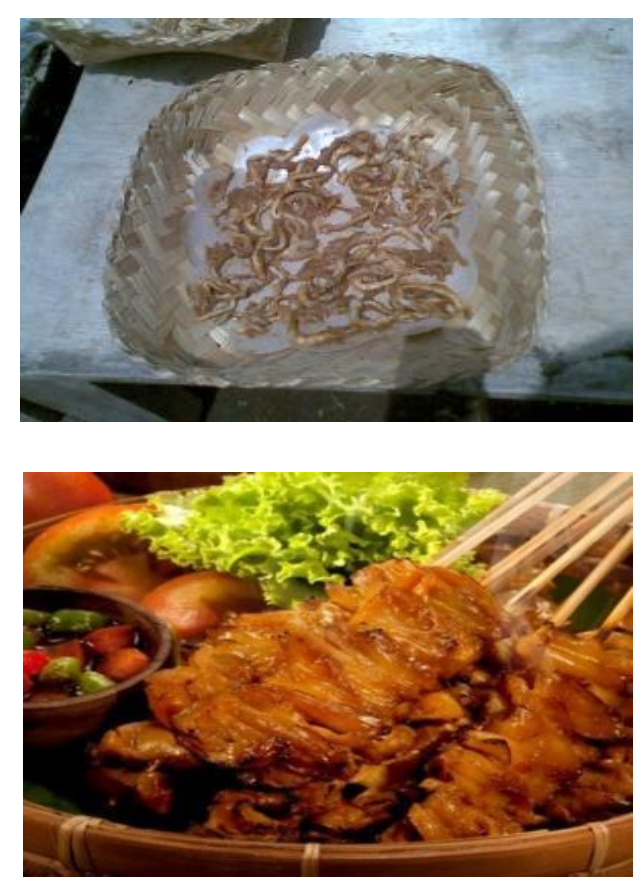

Gambar 3. Produk Olahan Jamur Tiram

Metode yang digunakan dalam kegiatan ini adalah, karena keterbatasan waktu dan anggaran, dengan membagikan brosur terkait cara dan langkah-langkah pembuatan ketiga produk olahan kepada para peserta pengabdian dan dilanjutkan dengan diskusi. Dengan metode ini diharapkan peserta penyuluhan dapat memahami dengan baik tentang prosedur atau langkah-langkah pembuatan produk olahan jamur tiram

\section{B. Evaluasi Kegiatan}

Kegiatan pengabdian mandiri yang dilaksanakan oleh Tim Pengabdian Fakultas Pertanian Universitas Mataram ini berlangsung sekitar 1 bulan pada bulan September 2019. Kegiatan pengabdian dimulai dari survey pendahuluan, yang dilanjutkan dengan pertemuan dengan 
Kepala Desa Karang Baru, Kecamatan Wanasaba sekaligus sosialisasi kegiatan pengabdian. Dalam pelaksanaannya, kegiatan pengabdian dirasa cukup berhasil, respon masyarakat, khususnya ibu-ibu rumahtangga peserta sangat positif dalam mengikuti semua kegiatan yang diprogramkan. Ibu-ibu peserta sangat antusias, sering mengajukan pertanyaanpertanyan, serta berpartisipasi penuh dalam melaksanakan seluruh kegiatan, dan yang membanggakan adalah keberhasilannya dalam membudidayakan tanaman jamur tiram sistem baglog serta memahami dengan baik bagaimana mengolah produk olahan berbasis jamur tiram.

Fenomena di atas dapat digunakan sebagai indikator adanya kemampuan peserta dalam aspek kognitif dan aspek afektif, yakni meningkatnya pengetahuan dan keterampilan masyarakat peserta pengabdian, akan tetapi belum dapat dijadikan sebagai ukuran untuk mengetahui apakah yang transfer pengetahuan dan keterampilan yang diintroduksi oleh tim pengabdian benar-benar telah dipahami serta dipraktekkan secara konsisten oleh para peserta. Diperlukan evaluasi yang lebih mendalam untuk mengetahui hal tersebut.

Faktor pendorong keberhasilan program ini adalah adanya respon yang sangat positif dari Kepala Desa Karang Baru. Mereka sangat mendukung serta turut hadir dalam acara pembukaan kegiatan ini, hal ini tentunya menambah semangat masyarakat peserta untuk mengikuti kegiatan ini. Hal lain yang menjadi faktor pendorong adalah cukup banyaknya tersedia bahan baku di lokasi. Sementara itu yang menjadi hambatan dari pelaksanaan kegiatan ini adalah terbatasnya anggaran dan waktu yang ada, serta lokasi kegiatan yang cukup jauh, sehingga pendampingan dan pengamatan yang lebih mendalam untuk mengetahui keberhasilan seluruh kegiatan yang diprogramkan tidak dapat diamati secara penuh.

\section{KESIMPULAN DAN SARAN}

\section{A. Kesimpulan}

Dari hasil kegiatan pengabdian yang dilakukan mulai dari kegiatan sosialisasi, penyuluhan sampai dengan kegiatan pelatihan, dapat ditarik beberapa kesimpulan sebagai berikut:

1. Para peserta penyuluhan menunjukkan respon positif dan berpartisipasi secara aktif terhadap seluruh kegiatan yang diprogramkan. Terjadi peningkatan ranah kognitif dan afektif peserta penyuluhan baik pengetahuan pengelolaan jamur tiram mulai dari cara perawatan sampai panen, dan juga peningkatan pengetahuan dalam membuat berbagai produk olahan berbahan baku produk jamur tiram

2. Aspek psikomotorik peserta penyuluhan/pengabdian juga meningkat, dimana peserta penyuluhan telah mampu melakukan teknik budidaya tanaman jamur tiram sistem baglog

\section{B. Saran}

Program pengabdian tentang pemanfaatan lahan pekarangan dengan budidaya tanaman jamur tiram baglog telah direspon sangat positif oleh para peserta, dan mempunyai potensi sebagai sumber tambahan pendapatan keluarga. Oleh karena itu agar program tersebut dapat berlanjut disarankan kepada Kepala Desa 
Karang Baru Kecamatan Wanasaba agar dimasukkan sebagai salah satu program kerja desa, terutama dalam hal peningkatan keterampilan budidaya jamur tiram dan pendampingan dalam wirausaha produk olahan jamur tiram.

\section{DAFTAR PUSTAKA}

Anonim. 2018. Profil Desa Karang Baru Kecamatan Wanasaba - Kabupaten Lombok Timur.

Ashari dan Saptana (2012). Potensi dan Prospek Pemanfaatan Lahan Pekarangan untuk Mendukung Ketahanan Pangan. Jurnal Forum Penelitian Agro-Ekonomika. Vol 3 No.1 Juli 2014

Daniel, M., Darmawati dan Nieldalina. 2005. PRA: Participatory Rural Appraisal: Pendekatan Efektif Mendukung Penerapan Penyuluhan Partisipatif dalam Upaya Percepatan
Pembangunan Pertanian. Penerbit PT Bumi Aksara. Jakarta.

Marikxon, 2019. Cara Budidaya Jamur Tiram di Rumah. https://www. maxmanroe.com/budidaya-jamurtiram.html

Nasution,G.2016. Kandungan Karbohidrat dan Protein Jamur Tiram Putih (Pleurotus ostreatus) Pada Media Tanam Serbuk Kayu Kemiri dan Serbuk Kayu Campuran. Jurnal Eksakta Vol 1. Medan

Sugiarso, Agus Riyadi, Rusmadi. 2017. Pemberdayaan Masyarakat Melalui Pemanfaatan Tanah Pekarangan (PTP) untuk Konservasi dan Wirausaha Agribisnis di Kelurahan Kedungpane Kota Semarang. Jurnal DIMAS - Volume 17, Nomor 2, November 2017. 